\title{
Belated comment to: 'What is Informatics?' (2007)
}

\author{
Stefan Gruner sg@cs.up.ac.za \\ Department of Computer Science, University of Pretoria, South Africa
}

When I wrote my above-mentioned letter to the editor of SACJ several years ago in 2007 (Gruner, 2007), I had not been aware of the fact that the Austrian computer pioneer Heinz Zemanek (19202014) had published an article of the same title already (in the year 1972) in the Management Informatics journal (Zemanek, 1972). In that publication, Zemanek had characterised informatics as a new type of engineering discipline-i.e., the informatician emerges as a new type of engineer for abstract objects, instead of material devices (Zemanek, 1972). His notion of 'abstract object' Zemanek had defined already four years earlier in the journal Elektronische Rechenanlagen (Zemanek, 1968): abstract objects can generally represent both the structure of linguistic expressions as well as the various sub-states of finite automata (Zemanek, 1968, p. 209). Zemanek re-confirmed his point of view in the Nachrichtentechnische Zeitschrift, in which he stated with regard to the goals and purposes of informatics: "man braucht dazu Ingenieure neuer Art: sie hantieren mit abstrakten Objekten, wie sie bisher nur in der Mathematik vorkamen"1 (Zemanek, 1973).

Though further definitions of 'informatics' have been numerous since then, Zemanek's early definition continues to possess-i.m.h.o.- - true core, and is also by-and-large compatible with the opinion which I had expressed in (Gruner, 2007) about this topic.

\section{References}

Gruner, S. (2007). 'What is informatics?' Letter to the editor of SACJ 39. Retrieved from http: //reference.sabinet.co.za/document/EJC28035

Zemanek, H. (1968). Abstrakte objekte. Elektronische Rechenanlagen, 10(5), 208-217.

Zemanek, H. (1972). What is informatics? Management informatics, 1(2), 43-52.

Zemanek, H. (1973). Philosophie der informationsverarbeitung. Nachrichtentechnische Zeitschrift, 26(8), 384-389.

\footnotetext{
Gruner, S. (2015). Belated comment to: 'What is Informatics?' (2007) [Letter to the Editor]. South African Computer Journal 57, 118-118. http://dx.doi.org/10.18489/sacj.v0i57.342

Copyright (C) the author(s); published under a Creative Commons NonCommercial 4.0 License (CC BY-NC 4.0).

SACJ is a publication of the South African Institute of Computer Scientists and Information Technologists. ISSN 1015-7999 (print) ISSN 2313-7835 (online).

1 "One needs for this purpose engineers of a new kind: they work with abstract objects which had hitherto only occurred in mathematics."
} 